\title{
Dergiabant
}

Cilt/Volume: 9, Sayı/Issue: 1

(Mayıs/May 2021)

\section{Miras Hukukunda Cari İlkeler Bağlamında Türk Mer'i Hukuku ve İslam Hukuku}

\section{Civil Law and Islamic Law in the Context of Current Principles in Inheritance Law}

\author{
Nusret Dede \\ Dr. Öğr. Üyesi, Bolu Abant İzzet Baysal Üniversitesi, İlahiyat Fakültesi, \\ İslam Hukuku Anabilim Dalı \\ Asst. Prof. Dr., Bolu Abant Izzet Baysal University, Faculty of Theology, \\ Department of Islamic Law \\ Bolu/Turkey \\ nusretdede@ibu.edu.tr \\ orcid.org/0000-0002-9650-3424

\section{Makale Bilgisi Article Information}

Makale Türü: Araştırma Makalesi

Geliş Tarihi: 24 Mart 2021

Kabul Tarihi: 27 Mayıs 2021

Yayın Tarihi: 30 Mayıs 2021

Yayın Sezonu: Bahar
Article Type: Research Article

Date Received: 24 March 2021

Date Accepted: 27 May 2021

Date Published: 30 May 2021

Publication Season: Spring

https://doi.org/10.33931/abuifd.902434

İntihal/Plagiarism

Bu makale özel bir yazılımla taranmış ve intihal tespit edilmemiştir. This article has been scanned by a special software and no plagiarism detected.

\section{Atıf/Cite as}

Dede, Nusret. “Miras Hukukunda Cari İlkeler Bağlamında Türk Mer'i Hukuku ve İslam Hukuku”. Dergiabant 9/1 (Mayıs 2021), 482-500. https://doi.org/10.33931/abuifd.902434

Copyright @ $\odot$ Published by Bolu Abant Izzet Baysal University Faculty of Theology, Bolu, 14030 Turkey. All rights reserved. https://dergipark.org.tr/tr/pub/dergiabant 


\title{
Miras Hukukunda Cari İlkeler Bağlamında Türk Mer'i Hukuku ve İslam Hukuku
}

Öz

Haklara ve ödevlere ehil kabul edilen gerçek kişilik olan insan, hayatı boyunca çalışıp didinerek elde ettiği mal üzerinde, hayattayken dilediği gibi tasarrufta bulunmaya hak sahibidir. Hukukun istisna ettikleri dıșında, hayatı boyunca malında kullanma, tüketme, ivazlı veya ivazsız olarak mülkiyetinden çıkarma vb. şekillerde dilediği gibi tasarruf edebilir. Ölümüyle de mülkiyet hakkı başta olmak üzere tereke adı verilen tüm hakları varislerine geçmektedir. Her hukuk sistemi hangi değerlerin terekeye intikal edeceği ve bunların varisler arasında hangi oranda paylaşılacağına dair birtakım kurallar belirlemiștir. Kur'an, sünnet, icma gibi delillere dayanan İslam Miras hukukunda mirasçılar ilahi teşri ile belirlenmiş ve mirastan alacakları paylarına farz adı verilmiştir. Türk mer'i hukukunda ise miras ile ilgili hükümler Medeni Kanun'da yer almaktadır. Medeni Kanun 1926'da İsviçre Medeni Kanun'u dilimize çevrilerek TBMM'de yasalaşmıș, 2001'de yapılan değişikliklerle yeniden kabul edilmiştir. Külli halefiyet, mansup mirasçılık, paylar, intifa hakkı, anne babanın mirasçllğı, evlilik dışı çocuğun mirasçllığı, evlatlığın mirasçılığı, mirastan ıskat, mirastan feragat, mirası ret, iade, mirasçıların miras bırakanın borçlarını ödemekte kendi mal varlıklarıyla müteselsilen sorumlulukları gibi birçok ilkede, İslam Miras Hukuku ile Türk mer'i miras hukukunun farkları bulunmaktadır. Çalışma bu ilkesel farkları incelemektedir. Anahtar kelimeler: İslam Hukuku, Medeni Hukuk, Miras, Feraiz, İlke.

\section{Civil Law and Islamic Law in the Context of Current Principles in Inheritance Law}

\begin{abstract}
Human beings, who is a real person who are accepted in rights and duties, have the right to dispose of their goods as they wish by working and trying throughout their life. Except for the exceptions of the law, the use, consumption, dismissal of property, etc., with or without gratuity, throughout as he wishes. After his death, all his rights, especially the property right, which are called taraka, pass to his heirs. Each legal system has determined some rules on which values will be transferred to the estate and at what rate they will be shared among the inheritors. In the Islamic Inheritance Law, which is based on evidences such as the Qur'ān, circumcision and ijmāc, inheritors were determined by divine division and their shares from the inheritance were called fard. In the Turkish land law, provisions regarding inheritance are included in the Civil Code. The Civil Code was translated into our language in 1926 and Swiss Civil Code was enacted in the Turkish Grand National Assembly, and it was re-accepted in 2001 with amendments. Islamic Inheritance Law in many principles such as general succession, appointed heir, shares, usufruct rights, inheritance of parents, inheritance of children out of wedlock, inheritance of adoption, abduction from inheritance, renunciation of inheritance, denial of inheritance, return of inheritance, joint responsibilities of heirs with their own assets in paying the depts of the inheritor. There are differences between Turkish legal inheritance law. The study examines these principal differences.
\end{abstract}

Keywords: Islamic Law, Civil Law, Inheritance, Farā’iḍ, Principle.

\section{Giriş}

Kıta Avrupası Hukuk sistemine dahil olan ülkelerde hukuk, özel ve kamu hukuku bölümlerine ayrılarak incelenmektedir. Bu taksimata göre özel hukuk; şahıs hukuku, aile hukuku, miras hukuku, eşya hukuku ve borçlar hukuku bölümlerinden 
oluşmaktadır. Kamu hukuku ise; anayasa hukuku, ceza hukuku, mali hukuk, devletler umumi hukuku ve usul hukuku veya muhakeme usulünden oluşmaktadır. Görüldüğü gibi Kara Avrupası Hukuk Sisteminde miras hukuku; özel hukukun bir bölümü olarak ele alınıp incelenmektedir. Özel hukuka aynı zamanda medeni hukuk adı da verilmektedir.

Türk Medeni Kanunu, ${ }^{1}$ İsviçre Medeni Kanun’u örnek alınarak hazırlanmış, 17 Şubat 1926'da TBMM'de kabul edilmiş, ${ }^{2} 4$ Nisan 1926'da yayımlanarak yürürlüğe girmiş, yeniden düzenlenen haliyle 22 Kasım 2001 tarihinde TBMM'de kabul edilmiş ve 8 Aralık 2001 tarihinde yayımlanarak 01 Ocak 2002 itibariyle yürürlüğe girmiştir. ${ }^{3}$ Çalışmamızda değerlendirmeler yeni TMK üzerinden yapılacak, lüzumu halinde eski TMK'ya da göndermelerde bulunulacaktır. TMK'nın içeriğine bakıldığında ise bu kanunun Kişiler Hukuku, Aile Hukuku, Miras Hukuku, Eşya Hukuku başlıklarını taşıyan toplam dört bölümden oluştuğu görülmektedir. Borçlar hukuku da hadd-i zatında medeni hukukun bir bölümü olmasına rağmen, Türk Borçlar Kanunu ${ }^{4}$ adıyla ayrıca hazırlanmış ve bunda da İsviçre Borçlar Kanunu örnek alınmıştır. TMK miras hukukunu, üçüncü kitabında, 495. Maddeden 682. Maddeye kadar düzenlemiştir. ${ }^{5}$

İslam hukukunun kanunlaştırılmasının ilk denemelerinden biri ${ }^{6}$ kabul edilen Mecelle-i Ahkam-ı Adliye; kısmen özel hukuk ve kısmen de kamu hukuku ile ilgili düzenlemeler sevketmiştir. Mecelle mesela, özel-kamu ayrımına göre kamu hukukunda incelenen usul hukuku ya da muhakeme usulü ile ilgili hükümleri Dâvâ, Beyyinât, Tahlîf gibi bölümlerde düzenlemiştir. Medeni hukukun kısmen şahıs, eşya, borçlar hukukunu ilgilendiren hükümlerini ise büyû', îcâr, kefâle, havâle, rehin, emânet, hibe, gasb, itlâf, hacir, ikrâh, şuf'a, şirket, vekâlet, sulh, ibrâ, ikrâr vb bölümlerde düzenlemiştir. Görüldügü gibi, anılan konular gibi yine medeni hukuk alanını ilgilendiren aile ve miras hukuku ile ilgili Mecelle'de herhangi bir hüküm bulunmamaktadır.7 Aile Hukuku ile ilgili düzenlemelerin Mecelle'de yer almamasından doğan bu eksiklik, bilahare Hukuk-ı Aile Kararnamesi8 hazırlanıp yürürlüğe konarak telafi edilmeye çalışılmakla birlikte, İslam miras hukukunun kanunlaştırması yapılamamıştır.

Türk Medeni Kanunu bundan böyle TMK kısaltmasıyla gösterilecektir.

Kabul edilme sürecinde TMK'ya yöneltilen eleştirilerle ilgili bk. Elif Dursunüst, "Kabul Edilme Sürecinde Türk Kanun-ı Medenîsi”, Usul İslam Araştırmaları 34/34 (31 Ekim 2020), 159-170; Erhan Taş, "Kabul Sürecinde Türk Medeni Kanunu'na Yönelik Bazı Eleștiriler”, Bingöl Üniversitesi Sosyal Bilimler Enstitüsü Dergisi 8/16 (2018), 649-670. TMK'nın yenilenme süreciyle ilgili bk. Ahmet Kılıçoğlu, "Medeni Kanunumuzu Nasıl Değiștirdik" Marmara Üniversitesi Hukuk Fakültesi Hukuk Araștırmaları Dergisi 22/3 (2016), 1717-1757. Türk Borçlar Kanunu (TBK), Resmi Gazete 6098 (11 Ocak 2011).

Türk Medeni Kanunu (TMK), Resmi Gazete 4721 (22 Kasım 2001).

Mecelle öncesinde gerçekleștirilen İslam Hukuku kanunlaştırma örnekleri için bk. Ceza Kanunname-i Hümayunu (1840), Arazi Kanunnamesi (1858).

Mecelle-i Ahkam-ı Adliye (Mecelle) (ts.).

Osmanlı Hukuk-ı Aile Kararnamesi (Konya: Mehir Vakfı Yayınları, 2017). 
Klasik fıkıh literatürüne bakıldığında, miras hukuku bir taraftan genel fikıh eserlerinin ferâiz adı verilen bölümlerinde konu edilirken ${ }^{9}$ bir taraftan da ilk dönemden itibaren müstakil eserlerde ele alınır hale gelmiştir. ${ }^{10}$ Bazı fıkıhçılar fıkhın hemen her konusunu ele aldıkları geniş hacimli eserlerinde ferâiz bölümüne yer vermeyip, bu alanda müstakil eserler kaleme almışlardır. ${ }^{11}$ Mesela el-Hidâye müellifi Merğînânî, ferâiz ilmini el-Ferâizu'l-Usmâniyye ${ }^{12}$ adıyla müstakil bir eser olarak ele almıştır. Bunun gibi bazı klasik fıkıh kitaplarında vasiyye bölümü yer almasına rağmen ferâiz bölümünün bulunmayışı, miras hukukunun, bu alanda yazılan müstakil eserlerle ayrı bir ilmî disiplin haline gelmiş olmasıyla izah edilebilir.13 Günümüzde ise İslam miras hukukunu ele alan müstakil eserlerin, geçmişte olduğu gibi telif edilmeye devam ettiği söylenebilir. ${ }^{14}$

İslam miras hukukuyla TMK'nın mirasçılar veya payları açısından karşılaştırıldığı tez ${ }^{15}$ ve makale ${ }^{16}$ bazında birçok çalışma mevcut olmakla birlikte,

9 Mesela bk. Ebu'l-Huseyn Ahmed b. Ebubekir Muhammed b. Ahmed Kuduri, Muhtasaru'l-Kudûrî, ed. Faik Akcaoğlu (İstanbul: Beka Yayıncılık, 2018), 284-292; Şemsüleimme es-Serahsî, el-Mebsût (Beyrut: Dâru'l-Ma'rife, 1414/1993), XXIX/136.

10 Feraiz alanında müstakil eser yazımı, fikıh mezheplerinin oluşum döneminden de önceye götürülmektedir. Sahabeden Zeyd b. Sabit'in (öl. 45/665) ilk feraiz risalesini yazdığı rivayet edilmektedir. Tabiinden Süfyan es-Sevrî̀nin (öl. 161/778) Kitâbü'l-Ferâiz'i ise müstakil feraiz eserlerinin günümüze ulaşan ilk örneklerden biridir. bk. Recep Özdirek - Ali Hakan Çavuşoğlu, "Süfyân es-Sevrî", Türkiye Diyanet Vakfi İslâm Ansiklopedisi (İstanbul: Türkiye Diyanet Vakfı Yayınları, 2010), XXXIII/24.

11 Abdurrahman Yazıcı, "Üç Ferâiz Metni Çerçevesinde Gelișen Müteahhirîn Dönemi Ferâiz Literatürü", Türkiye Araştırmaları Literatür Dergisi 11/22 (2013), 149.

12 Ahmet Özel, Hanefi Fıkıh Alimleri ve Diğer Mezheplerin Meşhurları (Ankara: TDV, 2014), 88.

13 Ali Bardakoğlu, "Ferâiz", Türkiye Diyanet Vakfi İslâm Ansiklopedisi (İstanbul: Türkiye Diyanet Vakfı Yayınları, 1995), XII/263.

14 Mesela bk. Yasin Ahmed İbrahim Derâdeke, el-Mîrâs fi'ş-Şerî́ati'l-íslâmiyye (Beyrut: Müessesetü'r-Risâle, 1983); Muhammed Ali es-Sâbûnî, el-Mevârî́s fi'ş-Şerî'ati'l-İslâmiyye fí Dav'i'lKitâbi ve's-Sünne (Mekke-i Mükerreme: Dâru'l-Hadîs, ts.); Ebü'l-Yakzân Atıyye el-Cübbûrî, Hükmü'l-Mîrâs fi'ş-Şerî̀ati'l-İslâmiyye (Bağdat: Dâru'n-Nezîr, 1969); Muhammed el-'Iyd elHatarâvî, er-Râid fî 'İlmi'l-Ferâiz (Medîne-i Münevvere: Mektebetü Dâri't-Türâs, ts.); Haseneyn Muhammed Mahlûf, el-Mevârîs fi'ş-Serî'ati'l-İslâmiyye (Mısır: Dâru'l-Kitâbi'l-'Arabî, 1954); Mustafa Müslim, Mebâhis fî́l'Imi'l-Mevârîs (Cidde: Dâru'l-Menâra, 2004); Muhammed b. Sâlih elUseymîn, Telhîsu Fıkhi'l-Ferâiz (Riyad: Medâru'l-Vatan, 1423/2002); Muhammed Abdürrahim elKişkî, el-Mîrâsü'l-Mukâran (Bağdat: Dâru'n-Nezîr, 1969); Muhammed eş-Șehhât el-Cündî, elMîrâs fi'ş-Şerî'ati'l-İslâmiyye (Kahire: Dâru'l-Fikri'l-Arabî, ts.); Berrâc Cum'a Muhammed Muhammed, Ahkâmü'l-Mevârîs fi'ş-Șerî'ati'l-İslâmiyye; Ali Himmet Berki, İslam Hukukunda Feraiz ve İntikal (İstanbul: Güzel İstanbul Matbaası, 1954); Ali Himmet Berki, İslam Hukukunda Feraiz ve İntikal (Ankara: Emel Matbaacılık, 1986); Ömer Nasuhi Bilmen, Hukuk-ı İslamiyye ve IstılahatI Flkhiyye Kamusu (İstanbul: Bilmen Basımevi, 1969), 5/207-407.

15 Zeynep Cerah, Gözetilen Hikmetler Açısından Fıkıh'ta Kadınların Mirası (Rize: Recep Tayyip Erdoğan Üniversitesi, Sosyal Bilimler Enstitüsü, Yüksek Lisans Tezi, 2012), 295; Abdurrahman Yazıcı, İslam Hukukunda Asabe Yoluyla Mirasçılık (İstanbul: İstanbul Üniversitesi, Sosyal Bilimler Enstitüsü, Doktora Tezi, 2011).

16 Alpaslan Alkış, "İslam Miras Hukuku İle Türk Medeni Kanun Miras Sisteminin Varisler Yönüyle Karşılaştırılması”, Çukurova Üniversitesi İlahiyat Fakültesi Dergisi (ÇÜiFD) 19/1 (26 Haziran 2019), 60-79; Abdurrahman Yazıcı, "Fıkıhta Bir Miras Meselesi Olarak Avliyye: Avl Halleri, Kaynağı ve Çözümlerin Değerlendirilmesi", İslam Hukuku Araştırmaları Dergisi 24 (Ekim 2014); Muhammed Çuçak, "İslam Miras Hukukunda Asabe Ve Bu Yolla Mirasçı Olmak", Süleyman Demirel Üniversitesi İlahiyat Fakültesi Dergisi 45 (31 Aralık 2020), 25-43; Hüseyin Tekin Gökmenoğlu, “İslam Miras Hukukunda 'Halefiyet', 'Dede Yetimi' ve 'Vacip Vasiyet'”, Dini Araştırmalar 1/3 (01 Haziran 1999); Kaşif Hamdi Okur, "İslam Hukukunda Miras Engeli Olarak Müslüman Ve 
Türk mer'i miras hukuku ile İslam miras hukukunda cari ilkelerin ele alınıp, bu yönüyle karşılaştırıldığı bir çalışmanın bulunmaması, bizi bu konuyu çalışmaya sevk etmiştir.

Hukukun süjesi olan insan ile mal veya eşya arasındaki ilişki, hukuk sistemlerinin temel konularından biri olarak hukuk tarihi boyunca önemini koruyagelmiştir. Birey ile mal veya eşya arasındaki sahiplik ve tasarruf yetkisi veren mülkiyet kavramını bireyden reddederek topluma veya devlete veren sosyalist veya komünist sistemlere karşın, mülkiyet bağını hiçbir kayıt ve sınırla kısıtlamadan bireye veren kapitalist sistemler, birbirlerine tamamen zit bir görüntü arz etmektedir.

Türk hukuk sistemi ise ferdî mülkiyeti kabul ederek, Türkiye Cumhuriyeti 1982 Anayasası'nın 35. Maddesinde mülkiyet ve miras hakkını birlikte şöyle düzenlemektedir:

"Herkes, mülkiyet ve miras haklarına sahiptir. Bu haklar, ancak kamu yararı amacıyla, kanunla sınırlanabilir. Mülkiyet hakkının kullanılması toplum yararına aykırı olamaz." ${ }^{17}$

Hukuk sistemlerinde mirasla ilgili düzenlemeler incelendiği zaman, bir kısmının aileyi koruyan $^{18}$, bir kısmının ise miras bırakanı koruyan, ${ }^{19}$ ferdiyetçi ${ }^{20}$ özelliklere sahip oldukları görülmektedir. Aileyi koruyan sistemler miras bırakana tereke üzerinde tasarruf etme yetkisi tanımamakta, böylece malın tamamının aileye kalması için hükümler koymaktadır. Buna karşın -Anglosakson hukuk sisteminde olduğu gibi- miras bırakanı koruyan sistemler ise, kişi hayatında iken tüm malı üzerinde sınırsız tasarruf yetkisine sahip olduğu gibi, aynı şekilde, öldükten sonra da tüm malı üzerinde sınırsız tasarruf etme yetkisini ölene vermektedir. Aslında mirasın aileye kalması ilkesiyle, miras bırakanın malında dilediği gibi ölüme bağlı tasarrufta bulunabilme ilkesi aynı amaca hizmet etmekle birlikte, bu iki ilke arasında bir bakıma çelişki de bulunmaktadır. ${ }^{21}$ Çünkü miras bırakan, ölüme bağlı tasarruf yetkisini dilediği gibi kullanarak, malını aile dışında kişi ve kurumlara da aktarabilecektir.

Öte yandan Sosyalist ${ }^{22}$ hukuk sistemleri ferdî mülkiyet kavramını baştan tanımadıklarından dolayı, ferdî mülkiyetin bir uzantısı olarak miras kavramını da tanımamakta, kişinin ölümünden sonra malvarlığının topluma veya onun

Gayrimüslim Arasındaki Din Ayrılı̆̆ı", Dinbilimleri Akademik Araştırma Dergisi 7/2 (01 Nisan 2007), 95-120; Hilal Özay, "İslam Miras Hukukunun Özellikleri", İslam Medeniyeti Araștırmaları Dergisi 3/2 (31 Aralık 2018), 203-224.; Abdurrahman Yazıcı, "Fıkıhta Meşhur Bir Miras Meselesi Olarak Ömeriyyeteyn: Kaynağı, Ortaya Çıktığı Haller ve Çözümü", Ondokuz Mayıs Üniversitesi Ilahiyat Fakültesi Dergisi 35/35 (01 Eylül 2013), 223-244; Abdurrahman Yazıcı, "İslam Miras Hukuku İle Türk Medeni Kanunu Miras Sisteminin Mukayesesi”, Ekev Akademi Dergisi, (ts.), 14. Türkiye Cumhuriyeti Anayasası (Türkiye Cumhuriyeti Anayasası), 2709 (18 Ekim 1982).

18 Ali Naim İnan vd., İnan Türk Medeni Hukuku Miras Hukuku (Ankara: Seçkin, 2008), 49, 50; Zahit İmre-Hasan Erman, Miras Hukuku (İstanbul: Beta, 1989), 3.

İnan vd., İnan Miras Hukuku, 50.

İmre - Erman, Miras Hukuku, 3, 4.

Selim Kaneti, "Türk Miras Hukukunun Anayasal Temelleri", Journal of Istanbul University Law Faculty 54/1-4 (12 Temmuz 2011), 237-244.

22 İmre - Erman, Miras Hukuku, 4. 
kurumlaşmış hali olan devlete kalması gerektiğini savunmaktadır. Bu görüşe toplumu koruyan ya da kolektivist görüş adı verilir. ${ }^{23}$ Böylece sosyalist sistem ne aileyi ne ferdi koruyan, buna mukabil toplumu, devleti koruyan bir görüntü arz etmektedir.

Türk hukuk sisteminde yer alan miras düzenlemeleri ise kısmen aileyi, kısmen de ferdi koruyan özellikler arz etmektedir. Buna göre Türk Miras Hukukunun hem aileyi hem de ferdi koruyan hükümler içermesi sebebiyle, karma yaklaşımı kabul ettiği söylenebilir. Nitekim TMK, sevk ettiği maddelerde yasal mirasçllığı düzenlediği gibi, miras bırakana mansup mirasçı belirleme imkânı da tanımaktadır. İslam hukuku ise yasal mirasçılığı temel kabul etmekle birlikte, irâdî mirasçılığı da tamamen reddetmemekte, sınırlı da olsa miras bırakana vasiyet yapma serbestisi getirerek, böylece dengeli bir yol çizmektedir.

Bu çalışmada miras hukukunda geçerli ilkeler bağlamında Türk Mer'î Hukuku ve İslam Hukuku incelenecektir.

\section{Türk Mer'î Miras Hukukunda Cari İlkeler}

Türk mer'i miras hukukunda tereke ${ }^{24}$ kişinin sağlığındaki mal varlığının tamamını ifade etmemektedir. Nitekim kişinin sağlığında mal varlığına dahil olan bazı haklar terekeye geçmediği gibi, sağlığında mevcut olmayan bazı haklar da terekeye geçebilmektedir. Mesela intifa hakkı, sükna hakkı, aksi kararlaştırılmadıkça irtifak hakları, adi ortaklık, aile ortaklığı, nafaka talep hakkı gibi haklar terekeye intikal etmemektedir. Yine, boşanma davası açma hakkı gibi kişiye sıkı sıkıya bağlı olan haklar da terekeye geçmez. Öte yandan kişiye sıkı sıkıya bağlı olmasına rağmen terekeye intikal eden fikri haklar, bir istisna teşkil etmektedir. Sağlığında mevcut olmadığı halde terekeye dahil olan hakka örnek olarak, kişinin sağlığında açtığı boşanma davası ölümünden sonra sonuçlanınca, hâkimin geriye dönük olarak tespit ettiği nafaka verilebilir. Nitekim bu hak, kişinin hayatındayken henüz mevcut olmamasına rağmen, ölümünden sonra doğmakta ve terekeye intikal etmektedir.

Mer'i hukukta miras bırakanın tüm malvarlığı terekeye dahildir. Tüm malvarlığı ifadesi ile, kişinin maddi değerle ölçülebilen, malvarlığının tüm aktifleri ve pasifleri kastedilmektedir. Yani mevcut malları, alacakları ve borçları, tamamıyla tereke kapsamındadır. Bundan mütevellit, mirasçılar mirası reddetmedikleri takdirde, miras bırakanın borçlarını, velev ki terekeyi aşsa bile, kendi mal varlıklarıyla ödemekle sorumludurlar.

TMK'ya göre yasal mirasçların belirlenmesinde zümre usulü ${ }^{25}$ esas alınmaktadır. Zümre usulü kısaca, soy bağını esas alarak miras bırakana yakınlığına göre kan hısımlarını belirli gruplara ayırarak, varislerin kimler olduğunu tespit etme yöntemidir denebilir. Buna göre kan hısımları dört zümreye ayrılırlar. Bunlardan ilk

İnan vd., İnan Miras Hukuku, 50, 51.

İlhan Öztrak, Miras Hukuku (Giriş-Kanundan Doğan Mirasçllık-Ölüme Bağlı Tasarruflar) (Ankara: Sevinç Matbaası, 1968), 11, 12.

25 İnan vd., Inan Miras Hukuku 85 vd.; İmre - Erman, Miras Hukuku, 12 vd.; Nûşin Ayiter - Ahmet M. Kılıçoğlu, Miras Hukuku (Ankara: Yetkin, 1989), 44 vd. 
üç zümre TMK'ya göre mirasçı iken, dördüncü zümre mirasçı kabul edilmemiştir. 1 . Zümre; miras bırakanın füruu yani oğlu/oğulları ve kızı/kızlarıdır. Birinci zümre, kız erkek ayrımı olmaksızın, eşit olarak mirasçı olur. ${ }^{26}$ Ayrıca burada halefiyet ${ }^{27}$ esası geçerlidir. ${ }^{28}$ Buna göre mesela miras bırakanın oğlu, kendisinden önce ölmüş ise ve oğlun oğlu/kızı yani miras bırakanın torunları varsa, babalarının yerine geçerek onun hakkını alır ve aralarında eșit olarak paylaşırlar. 1. Zümrenin mirasçılığı Medeni Kanun Md. 495'te düzenlenmiştir. 2. Zümre anne, baba ve bunların füruu yani kardeşlerdir. 3. Zümre büyükanne, büyükbaba ve onlardan olanlar yani amca, hala, dayı, teyzedir. TMK'da mirasçı olarak kabul edilmeyen 4. Zümre ise büyükanne ve büyükbabaların anne ve babaları ile bunların fürularıdır.

Zümrelerin mirasçılığında zümreler arası sıra esası geçerlidir. Buna göre 1. Zümrede mirasçı varken 2. Zümre hiçbir şekilde mirasçı olamaz. Bu ilke gereği miras bırakanın çocuğu varsa, anne babası mirasçı olamamaktadır. Aynı şekilde 2. Zümrede mirasçı varsa 3. Zümre de mirasçı olamaz.

TMK'ya göre yasal mirasçılar bu üç zümre kan hısmı ile sınırlı değildir. Bunun yanında kan hısmı olmayan $e^{29}$, evlatllk ${ }^{30}$ ve devlet $^{31}$ de yasal mirasçı olarak düzenlenmiştir.

Sadece meşru çocuklar değil, evlilik dışı olan çocuk ${ }^{32}$ da Medeni Kanun tarafından mirasçı kabul edilmiştir. ${ }^{33}$ Ancak bunun için miras bırakan ile soy bağının kurulması zorunludur.

Yasal mirasçılardan sağ kalan eşin ${ }^{34}$ mirasçılığı Medeni Kanun Md. 499'da düzenlenmiştir. Eşin miras payı, kimlerle birlikte mirasçı olduğuna göre değişiklik arz etmektedir. Buna göre eş; 1 . Zümre ile $1 / 4,2$. Zümre ile $1 / 2,3$. Zümre ile $3 / 4$ miras payı almakta, şayet üç zümreden de hiç kimse yoksa, terekenin tamamı eşe kalmaktadır.

Evlatlık da Medeni Kanun Md. 500’e göre, aynı öz çocuk gibi mirasçı olmaktadır. Evlatlığın füruu da çocukların füruu gibi halefiyet ilkesinden yararlanır. Buna göre evlatlık, evlat edinenden önce ölmüş ve evlatlı̆̆ın da çocuğu varsa babasının mirasını alır. Öte yandan evlatlığın mirasçılığı, karşılıklı tevarüs şeklinde olmayıp tek taraflıdır. Bu ilke gereği, evlat edinen ölünce evlatlık mirasçı olurken, evlatlık önce ölse evlat edinen evlatlığa mirasçı olamaz. Evlatlı̆̆ın mirasçılığı ile ilgili bir başka husus da evlatlığın kendi anne babası ile mirasçllık bağının devam ediyor

TMK. Md. 495.

TMK. Md. 495, 496.

Ayiter - Kılıçoğlu, Miras Hukuku, 48-50.

İnan vd., Inan Miras Hukuku, $116 \mathrm{vd.}$

İmre - Erman, Miras Hukuku, $34 \mathrm{vd.}$

İnan vd., İnan Miras Hukuku, 159-161; Ayiter - Kılıçoğlu, Miras Hukuku, 69.

İmre - Erman, Miras Hukuku, $31 \mathrm{vd.}$

TMK. Md. 498.

İmre - Erman, Miras Hukuku, 39 vd.; Ayiter - Kılıçoğlu, Miras Hukuku, 59 vd. 
olmasıdır. Yani evlatlık hem evlat edinene hem de kendi anne babasına aynı anda mirasçı olmaktadır. ${ }^{35}$

TMK'ya göre yasal mirasçıların sonuncusu devlettir. İlk üç zümrede kan hısmı yoksa, eş ve evlatlık da bulunmuyorsa veya hayatta değilse, miras bırakan da ölüme bağlı bir tasarrufta bulunmadığı takdirde, devlet mirasçı olmaktadır. ${ }^{36}$ Aynı şekilde, mirasçlların kimler olduğunun hiçbir şekilde bilinmemesi durumunda da devlet mirasçı olmaktadır. ${ }^{37}$ Ancak devletin mirasçılığı diğer mirasçıların mirasçılı̆̆ından farklılık arz etmektedir. Nitekim diğer yasal mirasçıların mirasçılığında külli halefiyet ${ }^{38}$ ilkesi geçerli iken ${ }^{39}$, devletin mirasçılığında bu ilke geçerli değildir. Bunun anlamı şudur: Miras bırakanın borçlarına karşı devletin sorumluluğu, terekede yer alan mallarla sınırlıdır. Bir başka deyişle devlet, ölenin borcuna varis olmamaktadır.

Yasal mirasçılık asıl, iradi mirasçılı $\mathrm{k}^{40}$ ise istisnadır. Herkes mirasının kaderini iradi olarak belirleme hakkına sahip olmakla birlikte, kimsenin bunu yapma zorunluluğu bulunmamaktadır. Kanun koyucu yasal mirasçılığı iradi mirasçlıktan ön planda tutmuş ve tercih etmiştir. Bunun yanında iradi mirasçılık mümkün olmakla birlikte bazı sınırlamalara tabidir. Bu sınırlamalar yasal mirasçıların hakkını korumaya yöneliktir. Bazı mirasçılara mahfuz hisse belirlenmesi bunu göstermektedir. İradi mirasçılık, sadece ölüme bağlı tasarruf ${ }^{41}$ adı verilen hukuki işlemlerle kurulabilmektedir.

Mer'i hukukta mirasla ilgili hükümlerin İsviçre Medeni Kanun'u örnek alınarak hazırlanan TMK'nın 495 ile 682. Maddeleri arasında yer aldığına daha önce değinilmişti. Dolayısıyla TMK, kaynağı itibarıyla beșerî bir kanundur. Bundan da öte, TMK'da yer alan birçok düzenleme, Türk örf-âdetleri ve toplum yapısından da kaynaklanmamaktadır.

İslam hukuku, sosyalist, komünist, kapitalist vb. sistemlerden farklı bir mülkiyet anlayışı getirdiği gibi, miras hukukunda da kendine özgü bir sistem takip etmiştir. Bu çerçevede “İslam'ın kendine mahsus bir veraset ve intikal usulü vardır."

\section{2. İslam Miras Hukukunda Cari İlkeler}

İslam miras hukukunda cari ilkeleri ise şöyle sıralamak mümkündür:

İlk olarak İslam miras hukuku kaynağı bakımından ilahidir. Bu çerçevede, mirasçılar ve hisseleri Şarî Teâlâ tarafından belirlenmiștir. İslam hukukunda, devlet,

TMK. Md. 500 ve 495.

İmre - Erman, Miras Hukuku, 38, 39.

TMK. Md. 594.

Külli halefiyet mirasçının murisin borçlarından kendi mamelekiyle de sınırsız olarak mesul olması demektir. bk. Ayiter - Kılıçoğlu, Miras Hukuku, 37. Ayrıca bk. Öztrak, Miras Hukuku, 14.

İmre - Erman, Miras Hukuku, 8-10.

İnan vd., Inan Miras Hukuku, 162.

İnan vd., Inan Miras Hukuku. 162 vd.

Osman Keskioğlu, Fıkıh Tarihi ve İslam Hukuku (Ankara: Diyanet İşleri Başkanlığı, 1999). 274. 
yapısı, organları, işleyişi gibi bazı hususlar, Kur'an'da detaylı hükümlerle değil, şûrâa ${ }^{43}$ gibi ilkesel hükümlerle belirlenmiştir. Buna mukabil miras hukuku; kimlerin mirasçı olacağına, mirasçıların paylarına, ${ }^{44}$ mirasın taksiminde dikkat edilmesi gereken esaslara $^{45}$ kadar detaylı olarak Kur'an'da belirlenmiştir.

İslam'da hemen her hüküm, tedriç ilkesine riayet edilerek konulmuştur. Bu çerçevede miras hükümleri de tedricen meşru kılınmıştır. Bu çerçevede; mirasla ilgili henüz bir ayetin inmediği, bir belirlemenin bulunmadığı zaman diliminde, sadece erkeklerin mirasçı kabul edilmeleri gibi cahiliye dönemi uygulamaları devam etmiş, hicret sonrası oluşan "muâhât" (kardeşlik anlaşması) çerçevesinde, birbirleriyle kardeş ilan edilenler arasında mirasçılık cereyan etmiş, bilahare ölüm anı geldiğinde miras bırakanın vasiyet etmesi emri gelmiş ${ }^{46}$, sonrasında ise akrabaların birbirlerine daha yakın oldukları ifade edilerek, akrabalar arasında tevarüs cereyan edeceği meşru kılınmıştır. ${ }^{47}$

Muris hayatı boyunca kazandığı malda, hayatta iken sınırsız şekilde tasarruf etmeye yetkilidir. Bunun tek istisnası, hukukun koyduğu bazı sinırlamalardır. ${ }^{48}$ Kişinin hayatında iken yapacağı ve tenfîzi ölüm sonrasında gerçekleşecek olan vasiyet ile, malında ölüm sonrası tasarrufta bulunma imkânı da bulunmaktadır. Ancak şu unutulmamalıdır ki; Sa'd b. Ebî Vakkâs (öl. 55/675) hastalığı sırasında kendisini ziyarete gelen Rasûlullah'a, bir kızından başka mirasçısı olmaması dolayısıyla tüm malını vasiyet etmeyi düşündüğünü söylemiş, bunun üzerine Hz. Peygamber buna izin vermemiş, yarısını teklif ettiğinde yine izin vermemiş, üçte birini vasiyet etmeyi sorduğunda ise, bu orana dahi pek hoş bakmamakla birlikte izin vermiş ve "mirasçılarını senden sonra zengin bırakman, onları insanlara avuç açan yoksul kimseler olarak bırakmandan daha hayırlıdır." buyurmuştur. ${ }^{49}$ Buna göre, gerekli olmadığı halde vasiyet bırakmak, fıkıh mezheplerince tavsiye edilmemektedir. Kişinin vasiyet yapmayı tercih etmesi durumunda da bu yetkisi sınırsız değildir. Ölüme bağlı tasarruflar çerçevesinde, terekesinin teçhiz-tekfin masrafları ile borçların ödenmesinden sonra arta kalan miktarın ancak 1/3'ünde tasarrufta bulunabilecektir. ${ }^{50} \mathrm{Bu}$ durumda terekenin kalan 2/3'ü ise tüm varisler lehine mahfuz hisse olarak korunmaktadır. Tasarruf nisabını aşıp mahfuz hisseye tecavüz edecek şekilde yapılan vasiyet, Hanefiler, Şafiiler, Hanbeliler, Zeydîler ve İmamîlere göre

\footnotetext{
43 Kur'an-ı Kerim Meâli, çev. Halil Altuntaş - Muzaffer Şahin (Ankara: Diyanet İșleri Başkanlığı, 2012), Âl-i İmrân, 3/159; Şura, 42/38. 
muteber olmakla birlikte icrası varislerin iznine mevkuftur, 51 yani varisler izin verirlerse vasiyet icra edilir, vermezlerse vasiyet geçersiz olur.

Sadece karı ve kocadan veya anne baba ve çocuklardan oluşan, toplumun en küçük yapı taşına modern dönemde çekirdek aile adı verilmektedir.52 Buna büyükanne, büyükbaba, amca, hala, dayı, teyze gibi akrabaları da eklediğimizde geniş aile ${ }^{53}$ oluşmaktadır. ${ }^{44}$ Sayılanlara ek olarak kayın hısımlarını ve sözleşmeyle ailede çalışan işçi ve hizmetlileri de dahil ettiğimizde, en geniş anlamda aileden bahsetmiş oluruz. ${ }^{55}$ Ayetlerde yer alan mirasçllar incelendiğinde, bunların belirlenmesinde sadece çekirdek aile değil, geniş ailenin de dikkate alındığı görülmektedir. Zümre sistemini esas alan TMK, çocuğun varlığı durumunda anne babayı mirastan mahrum ederken, İslam hukukunda ashab-ı feraiz ve asabe ile kan hısımlarına daha geniş bir çerçevede mirasın ulaşımı sağlanmış olmaktadır.

İslam Hukukunda her hak sahibine mirastan payı verildiğinden dolayı, varise vasiyet yoktur ${ }^{56}$. Çünkü varisler de bunların terekeden alacakları paylar da Şârî Teâlâ tarafından belirlenmiştir. Bu belirleme üzerine ayrıca vasiyete ihtiyaç bulunmadığı gibi, varise vasiyet edilmesi durumunda da ilgili hadis gereği bu vasiyet geçersizdir. Bu durum, Şâri'in belirlediği farz paylarda gözettiği dengenin değiștirilmesi gibi değerlendirilmiştir.

İslam miras hukukunda temel mirasçılık sebepleri karâbet (kan bağı veya rahim yoluyla oluşan akrabalık) ve nikahtır. ${ }^{57}$ Nitekim ashab-ı feraiz, asabe ve zevi'lerham, karâbet sebebiyle; eş ise nikah sebebiyle mirasçı olmaktadır.

İslam Hukukunda miras bırakanı öldürme suçu, mirastan mahrum olma sebebidir58. Bunun dışında miras bırakanın ölüme bağlı tasarrufuyla varislerinden birini mirasçllıktan çıkarmass ${ }^{59}$ söz konusu değildir.

Ölümle birlikte mirasın varislere cebrî intikali söz konusudur. Buna göre miras bırakan, varisi reddedemez ve onun mirasçı olmasına da engel olamaz. Varisin

Karaman, Mukayeseli İslâm Hukuku, 1/437.

TMK. Md. 185.

TMK. Md. 335-363.

54 Ender Ethem Atay vd., Temel Hukuk Bilgisi, ed. Hüseyin Özcan (Eskișehir: Anadolu Üniversitesi, 2020), 177.

55 Murat Topuz vd., Medeni Hukuk Bilgisi, ed. Hayriye Şen Doğramacı (Eskişehir: Anadolu Üniversitesi, 2020), 59.

56 Ebû Abdillah Muhammed b. Yezid el-Kazvînî İbn Mâce, Sünen (Dâru İhyâ'i'l-Kitabi'l-Arabiyye, ts.), II/906 (2714); Buhârî, "Vesâyâ", 6; Nesâî, Vesâyâ, 5 (3671).

57 el-Cübbûrî, Hükmü'l-Mîrâs fi'ş-Şerî'ati'l-İslâmiyye, 35-37; el-Hatarâvî, er-Râid fî 'Ílmi'l-Ferâiz, 7-8; el-Useymîn, Telhîsu Fıkhi'l-Ferâiz, 7. Mezhepler arasında görüş farklılıkları bulunmakla beraber velâ da mirasçılık sebepleri arasında sayılmaktadır. Mesela Hanefiler velânın mirasçılı̆̆ının nesh olmadığı görüşündedir. Buna göre azatlı köle ve kendileriyle velâ sözleşmesi yapılan kimseler de velâ sebebiyle mirasçı olmaktadır. 
kendisini Şârî yerine koyarak mirasçı atamas ${ }^{60}$ söz konusu olmadığı gibi, varis de mirası reddedemez.

İslam'da yetimlerin bakılıp büyütülmesi ve korunması son derece teşvik edilmesine rağmen, ${ }^{61}$ cahiliye döneminde uygulanan evlatlık müessesesi İslam Hukukunda kaldırılmış,62 böylece nesebin karışması gibi toplumsal önemli bir problemin oluşması engellenmiştir. Evlatlık kurumu kaldırıldığı gibi, İslam miras hukukunda evlatlık mirasçı da değildir. Bununla birlikte bakılıp büyütülen yetim vb. çocuklara vasiyette bulunmanın önünde herhangi bir engel bulunmamaktadır. Hatta velâyı mirasçılık sebebi gören mezheplere göre, bu kişilerle velâ anlaşması yapılarak tevârüs bağı da kurulabilir.

Terekenin varislere intikalinde külli halefiyet söz konusu değildir63. Bunun gereği olarak mirasçılar, miras bırakanın terekeyi aşan borçlarından sorumlu olmamaktadırlar. Terekede yapılacak işlemler sırasıyla teçhiz-tekfin, borçların ödenmesi, vasiyetin yerine getirilmesi, sonra da kalanın mirasçlar arasında bölüşülmesidir.

\section{Değerlendirme}

TMK mirasçıları, kanuni mirasçılar ${ }^{64}$ ve mansup mirasçılar ${ }^{65}$ olarak ikiye ayırmak suretiyle miras hukukunu kanunlaştırmıştır. ${ }^{66}$ İslam Hukukunda ise ilke olarak mansup mirasçllık söz konusu değildir. ${ }^{67}$ Türk mer'i hukukunda kanuni mirasçılar; miras bırakanın kan hısımları, eş, evlatlık ve hazine ya da devlettir. İslam

60 TMK. Md 516'da olduğu gibi.

61 Mesela bk. el-Bakara 2/83, 177, 215, 220; en-Nisa 4/36, 127; el-Enfâl 8/41; el-Haşr 59/7; el-İnsân 76/8; el-Fecr 89/17; el-Beled 90/16; ed-Duhâ 93/6; Müslim, Sahîh, .Zühd, 42 (2983); Muhammed b. İsa b. Sevra b. Musa b. Dahhâk Tirmizi, Sünen (Beyrut: Dâru'l-Ğarbi'l-İslami, 1998), el-Birr ve'sSila, 14 (1917).

62 el-Ahzâb 33/4.

63 Burada halefiyete kısaca değinmekte yarar bulunmaktadır. Kelime anlamı itibarıyla halefiyet, birinin yerine geçmiş olma halini ifade etmektedir. bk. D. Mehmet Doğan, Büyük Türkçe Sözlük (İstanbul: İz Yayıncıllk, 1996). Halefiyet md. 453. Hukuki bir terim olarak ise halefiyet, bir kimseye ait olan hakların başka birine geçmesidir. Bu kavram Borçlar hukukunda kullanıldığı gibi Miras hukukunda da kullanılmaktadır. Bununla birlikte miras hukukunda kavramın iki farklı kullanımı söz konusudur. Bunlardan biri varislerden birinin hayatta bulunmaması durumunda füruunun onun yerine geçerek mirasçı olmasını ifade etmektedir. İslam Hukukunda dede yetimi tartışmaları, zevi'l-erhamda halefiyet, modern hukukta 1. Zümre varislerin mirasçılığında halefiyet bununla ilgilidir. Diğeri ise varisin miras bırakanın yerine geçmesi, bir bașka ifadeyle ölenin terekesinin mirasçılara geçmesini ifade etmektedir. Bu da külli ve cüz'i halefiyet olmak üzere ikiye ayrılmaktadır. Modern hukukta terekenin aktif ve pasifiyle bir bütün olarak varislere intikal etmesine külli halefiyet adı verilmektedir. İslam hukukunda varislerin miras bırakanın borçları karşısındaki mali sorumlulukları tereke ile sınırlı olduğundan, bir başka deyişle terekenin tamamı değil sadece borca tekabül etmeyen kısmı varislere intikal ettiğinden, buna da cüz'i halefiyet adı verilmektedir. İnan vd., İnan Miras Hukuku; İmre - Erman, Miras Hukuku. 118 vd.; Ayiter - Kılıçoğlu, Miras Hukuku. $101 \mathrm{vd}$.

65 İnan vd., Inan Miras Hukuku; İmre - Erman, Miras Hukuku. 118 vd.; Ayiter - Kılıçoğlu, Miras Hukuku. 101 vd.

66 İnan vd., İnan Miras Hukuku. 71.

67 Hayreddin Karaman, Mukayeseli İslâm Hukuku (İstanbul: Nesil Yayınları, 1996), 1/497. 
Hukukunda ise yasal mirasçı olarak ashab-ı ferâiz, asabe, zevi'l-erham grupları bulunmaktadır ve bunlar sırasıyla miracı olurlar. Miras bırakanın, malının 1/3'ünü geçmeyecek şekilde, yasal mirasçıları dışındaki kişi veya kurumlara yapacak olduğu vasiyetin $^{68}$ ise mansup mirasçllığa benzediği söylenebilir.

Türk mer'i hukuk sisteminde intifa hakkı TMK Md. 568'de düzenlenmiştir. ${ }^{69}$ Ancak İslam miras hukukunda terekede "intifa hakkı" söz konusu değildir. ${ }^{70}$

İslam Hukukunda miras bırakanın füruu bulunsun veya bulunmasın, anne ve baba daima, her halükârda mirasçı olmaktadır. Hâlbuki TMK 1. Zümrenin varlığı durumunda anne babayı mirasçı kabul etmemektedir. "Altsoyu bulunmayan miras bırakanın mirasçlları, ana ve babasıdır."71 Yani ölenin çocuğu varsa hatta çocuğu bulunmayın evlatlığı varsa, anne-babası mirasçı olamamaktadır.

Nesebi sahih olmayan çocuk İslam Hukukunda varis olamazken ${ }^{72}$ TMK'da evlilik dışı çocuk mirasçı olarak kabul edilmiştir. ${ }^{73}$

TMK miras payında kadın ve erkek arasında mutlak bir eşitlik gözetmektedir. Nitekim yasal mirasçılardan kan hısımlarını düzenlerken ilk olarak 1. Zümreyi, miras bırakanın altsoyunu ele almış ve "Miras bırakanın birinci derecede mirasçıları onun altsoyudur. Çocuklar eşit olarak mirasçıdırlar."74 şeklinde düzenlemiştir. Yine 2. Zümreyi düzenlerken "Altsoyu bulunmayan miras bırakanın mirasçlları, ana ve babasıdır. Bunlar eşit olarak mirasçıdırlar.” ifadesiyle düzenlemiştir. Aynı durumu 3. Zümre mirasçıların Md. 497'de yer alan düzenlemesinde de görmek mümkündür. İslam Hukukunda ise kadın ile erkek bazen eşit pay alırken, çoğu kez de erkeğin kadından fazla pay alması söz konusudur. Mesela miras bırakanın bir oğlu ile bir kızı beraber bulundukları zaman, oğlu kızının iki katı pay almaktadır. Aynı durumda iki kız olursa kızlar 2/3'ü aralarında paylaşırlar. Oğlu yok sadece bir kızı varsa, mirasın yarısı kızındır. Anne babanın mirasçılığına gelince; miras bırakanın çocuğu veya kardeşi hayatta ise annesi de babası gibi $1 / 6$ hisse alır. Ama oğlu veya kardeşi yoksa anne babası ikili birli mirasçı olacaktır. ${ }^{75}$ Verdiğimiz örneklerde görüldüğü üzere, kadın ile erkeğin İslam hukukuna göre mirastaki paylarında mutlak bir eşitlik söz olmadığı gibi, her durumda ikili birli, erkeğin payının kadının payının iki katı olması da söz konusu değildir. Bunun hikmetlerinden biri olarak, erkeğin mehir ve nafaka

Karaman, Mukayeseli İslâm Hukuku, 1/499.

Ayiter - Kılıçoğlu, Miras Hukuku. 232, 233. Ayrıca bk. TMK. Md. 517, 601, 652.

Karaman, Mukayeseli İslâm Hukuku, 1/499.

TMK. Md. 496.

Ahmet Şerbasi, Íslam Fıkhı, çev. Mustafa Özcan vd. (İstanbul: Özgü Yayınları, 2011). 475-476.

TMK. Md. 498.

TMK. Md. 495.

en-Nisa 4/11. 
ödemekle sorumlu ${ }^{76}$ olmasına rağmen, kadının mehir ve nafaka alacaklısı olması zikredilebilir. ${ }^{77}$

Evlat edinme müessesesi İslam'da kaldırılmış olup ${ }^{78}$ bu hukuki düzenlemenin bir sonucu olarak evlatlığın evlat edinene mirasçllı̆ı da söz konusu değildir. TMK'da ise evlatlık, öz çocuk gibi mirasçı olmakta, bununla birlikte öz anne babasına mirasçllığ da devam etmektedir. ${ }^{79}$

Miras bırakanın varisini mirastan ıskat etmesi ${ }^{80}$ ya da varisin mirası reddetmesi ${ }^{81}$ İslam Hukukunda söz konusu değildir. Ama TMK mirasçılıktan çıkarmayı $^{82}$ ve mirası reddi 83 oldukça detaylı bir şekilde düzenlemiştir. ${ }^{84}$

Miras sistemlerinde miras bırakanın borçları ile ilgili olarak, tereke mevcudu ile sorumluluk ve kişisel mal varlığı ile sorumluluk olmak üzere iki farklı anlayış bulunmaktadır. ${ }^{85}$ TMK'nın kabul ettiği külli halefiyet ilkesi ${ }^{86}$ gereği, aktifi ve pasifiyle, miras bırakanın tüm mal varlığ mirasçılara intikal ettiğinden ${ }^{87}$, varisler miras bırakanın tüm borçlarını, yeterse terekeden yetmezse kendi mal varlıklarından ve müteselsilen ${ }^{88}$ ödemek zorundadır. Öyle ki bu durum "başka hiçbir medeni kanunda Türk ve İsviçre Medenî Kanunlarında olduğu kadar sert bir şekilde düzenlenmiş değildir."89 Miras bırakanın özellikle terekeyi aşan borcu varsa, bunu kendi mal varlıklarından ödemek istemeyen varisleri bu yükümlülükten kurtarmak amacıyla, mirasın reddi ${ }^{90}$ müessesesi kabul edilmiştir. İslam Hukukunda ise mirasın reddi müessesesi bulunmadığı gibi, buna ihtiyaç da bulunmamaktadır. Çünkü varislerin miras bırakanın borçlarını ödeme yükümlülükleri, tereke ile sınırlıdır. Borcun terekeyi aşan miktarını varisler kendi mallarından ödemekte serbest olmakla birlikte, böyle bir zorunluluk söz konusu değildir. Tereke üzerinde sırasıyla ilk olarak teçhiztekfin masrafları çıkarılır, sonra borçlar ödenir, vasiyet varsa, kalan miktarın $1 / 3$ 'ünden vasiyet yerine getirilir, bundan sonra arda kalan miktar ise varisler arasında usulüne uygun olarak pay edilir.

Tasarruf nisabı ve mahfuz hisse konusunda da temel bazı farklar söz konusudur. TMK bazı varisleri diğerlerine veya bizzat miras bırakana karşı koruyup

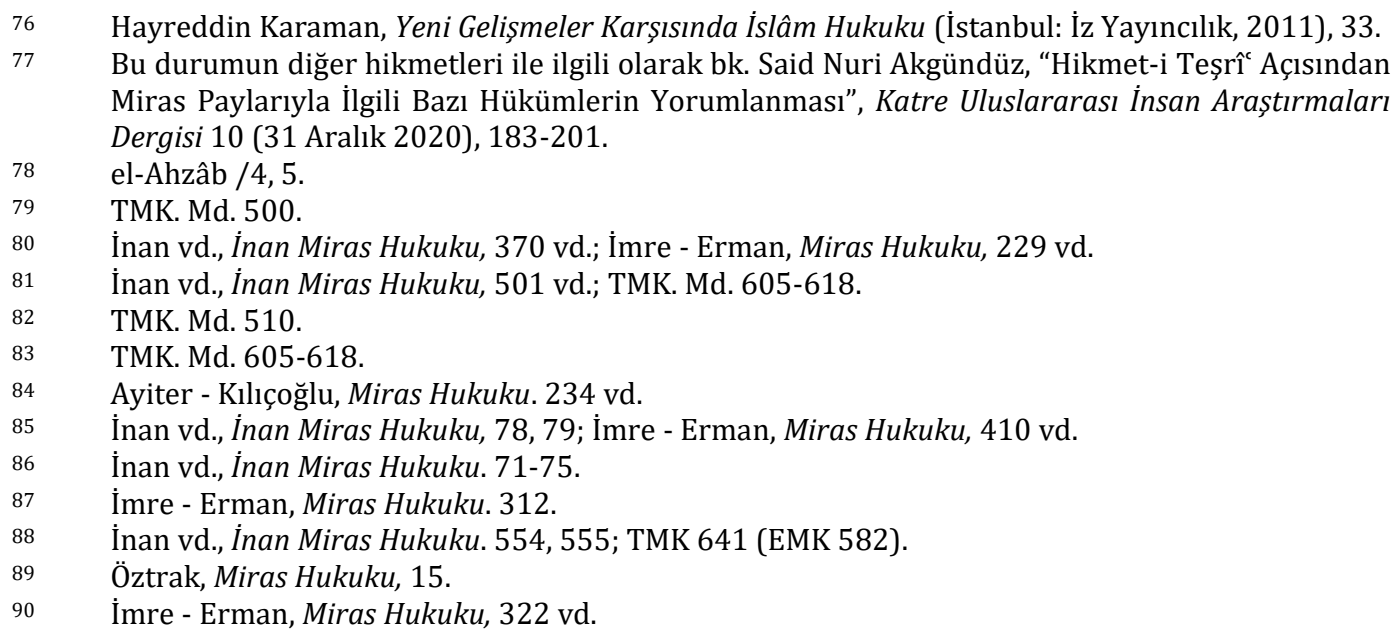


onların hisselerini mahfuz hisse olarak adlandırırken, miras bırakanın dilediği gibi işlem yapmakta serbest olduğu kısma da "tasarruf edilebilir kısım" adını vermiştir. ${ }^{91}$ Mirasçllar arasında altsoy, ana baba ve eş, saklı pay sahibi mirasçılar olarak düzenlenmiştir. ${ }^{22}$ Saklı pay, altsoy için yasal miras payının $1 / 2$ 'si, ana ve babadan her biri için yasal miras payının 1/4'ü, sağ kalan eş için altsoy veya ana baba zümresiyle birlikte mirasçı olması halinde yasal payının tamamı, diğer hallerde yasal miras payının 3/4'üdür. ${ }^{93}$ Eski TMK mahfuz hisseyi 453. Maddesinde düzenlemekteydi ve 3. bendinde kardeşlerden her biri için kanuni miras hakkının 1/4'ü mahfuz hisse olarak belirlenmişti. Ancak yapılan değişiklikle bu hüküm kaldırılmış ve kardeşler mahfuz hisse sahibi olmaktan çıkarılmışlardır. ${ }^{44}$ İslam hukuku ise herhangi bir mirasçının hissesini diğerinden ayrı olarak koruma altına almamış, tüm mirasçıların hisselerini korumuştur. Nitekim miras bırakanın vasiyet gibi ölüme bağlı hukuki işlemlerle malında tasarruf edebileceği kısım azami 1/3'tür. Kalan 2/3 ise sadece belli mirasçllar için değil, tüm mirasçlar lehine korunmuş mahfuz hissedir.

Karşılıklı veya karşılıksız olarak yapılacak bir sözleşmeyle mirastan feragat ${ }^{95}$ TMK'da kabul edilmesine rağmen ${ }^{96}$ İslam hukukunda söz konusu değildir. Türk mer'i hukukuna göre varis, miras bırakan ile yapacağı ivazlı veya ivazsız (karşılıklı veya karşılıksız) bir sözleşme ile mirastan feragat edebilmektedir. Ancak bu sözleşme İslam hukukunda geçersizdir.

Kişi hayattayken malı üzerinde yasak olmayan her tasarrufu yapabileceği gibi, çocuklarına bazı harcamalar yapması ve hediyeler alması da mümkündür. Burada da asıl olan çocukları arasında eşit davranmasıdır. Çünkü Nu'mân b. Beşî́'e babası bir bağıșta bulunmuș, Hz. Peygamber, "Diğer tüm çocuklarına da benzerini bağıșladın mı?" diye sormuş, babası hayır deyince, ona bağışladığını geri almasını söylemiştir. ${ }^{97}$ Buna göre miras bırakan, malı üzerindeki tasarruflarında muhtemel mirasçllar arasında adalete riayet ederek davranmalıdır. Ancak miras bırakan, hayattayken çocukları arasında fark gözeterek yaptığı harcamaların, vefat sonrasında geri alınması söz konusu değildir. Miras bırakanın varislerinden birine diğerlerinden farklı olarak yaptığı hediye verme, eğitim yardımında bulunma, evlendirme masrafları gibi hayattaki kazandırmaların geri verilmesini veya terekeden mirasa mahsup edilmesini

bk. TMK. Md. 505 vd.

İnan vd., İnan Miras Hukuku, 308 vd.; Ayiter - Kılıçoğlu, Miras Hukuku, 171 vd.; TMK. Md 506.

Bk. TMK. Md. 506 vd.

Türk Medeni Kanunu (Eski) (TMK (Eski)), Resmi Gazete 743 (17 Şubat 1926), Madde 453 (Değişik: 14/11/1990 - 3678/12 md.).

95 İnan vd., Inan Miras Hukuku, 269-274; İmre - Erman, Miras Hukuku, 181 vd.; Ayiter - Kılıçoğlu, Miras Hukuku, 147 vd.

TMK. Md. 528.

97 Ebû Abdillah Muhammed b. İsmail Buhârî, Sahîh (Dâru Tavkı'n-Necât, 1422), Hibe, 12 (2586); Müslim, Sahîh. Hibât, 9-19 (1623-1624). 
düzenleyen iade ${ }^{98}$ müessesesini de TMK kabul etmesine rağmen, ${ }^{99}$ İslam Hukukunda iade bulunmamaktadır.

Varis TMK'ya göre iki durumda mirastan hiçbir şey alamamaktadır. ${ }^{100} \mathrm{Bu}$ durumlar, mirastan mahrumiyet ${ }^{101}$ ve mirasçllıktan çıkarma ${ }^{102}$ durumudur. ${ }^{103}$ TMK Md. 578'de düzenlenen mirastan yoksunluk sebepleri, miras bırakanı kasten ve hukuka aykırı şekilde öldürmek veya öldürmeye teşebbüs, sürekli şekilde ölüme bağlı tasarruf yapamayacak hale getirme, vasiyet yapmasını veya vasiyetinden dönmesini aldatmak, zorlamak, korkutmak suretiyle sağlama veya engelleme, vasiyetini ortadan kaldırma ve bozma şeklinde özetlenebilir. Görüldüğü gibi TMK'daki mirastan yoksunluk sebepleri, İslam hukukundaki mirastan mahrumiyet sebepleri104 ile temelde benzeşmektedir. Şu kadar farkla ki, İslam hukukunda şer'an belirli mahrumiyet sebepleri bulununca, dava açmaya gerek olmaksızın kişi mirastan mahrum olmaktadır. Öte yandan, mirasçılıktan çıkarma (ıskat) müessesesi İslam hukukunda bulunmamaktadır.

Saklı paylarını alamayan mirasçılar TMK'ya göre tenkis davası ${ }^{105}$ açarak saklı paylarını talep edebilirler. İslam hukukunda ise miras bırakanın tasarruf nisabını aşacak şekilde yaptığı vasiyet, yani varislerin saklı payına tecavüz eden kısım, dava açmaya gerek olmaksızın, hukuken geçersizdir.

Mirasın paylaşılmasında kazâî taksim ve rızâî taksim olmak üzere iki yöntem uygulanmaktadır. Hepsi tam eda ehliyetine sahip olan mirasçllar kendi aralarında anlaşarak, kazâ (yargı) müessesesine başvurmaksızın, mirasın paylaşımını yapabilecekleri gibi (rızâi taksim), varislerden birinin yargı yoluna başvurmasıyla, hâkim tarafından da miras taksim edilebilmektedir (kazâî taksim).106 Rızâî taksimde varislerden birinin karşılıklı veya karşılıksız olarak terekeden hiçbir şey almaması, tüm varislerin eşit pay alması veya farklı oranlarda paylaşmalarında herhangi bir engel bulunmamaktadır. İslam Miras Hukuku ile ilgili eserlerin sulh, muhârace107,

\footnotetext{
98 İnan vd., İnan Miras Hukuku. 581 vd.; İmre - Erman, Miras Hukuku, 464 vd.; Ayiter - Kılıçoğlu, Miras Hukuku, 289 vd.

99 TMK. Md. 669-675.

100 Şakir Berki, “Türk Miras Hukukunun Esasları”, Ankara Üniversitesi Hukuk Fakültesi Dergisi 11/3 (01 Mayıs 1954), 183-184.

$101 \quad$ TMK. Md. 578.

102 TMK. Md. 510-511.

103 İnan vd., Ínan Miras Hukuku, 471, 213 vd.; İmre - Erman, Miras Hukuku, 281 vd.

104 "Kâtil mirasçı olamaz." Tirmizi, Sünen, Feraiz, 17 (2110).

105 İnan vd., İnan Miras Hukuku, 387 vd.; İmre - Erman, Miras Hukuku, 242 vd.; Ayiter - Kılıçoğlu, Miras Hukuku, $192 \mathrm{vd}$.

106 Abdullah Çolak, İslam Aile Hukuku (İstanbul: Ensar, 2018), 273.

107 Ali Himmet Berki tehârücü şöyle tanımlamaktadır: Tehârüc, miras hukuku örfünde, mirasçllardan bir kısmının belirli bir şey veya hisse üzerinde uzlaşarak mirastan çıkması demektir. bk. Berki, Íslam Hukukunda Feraiz ve Intikal, 157; Mehmet Erdoğan'ın tanımı ise örneğiyle birlikte şöyledir: Tehârüc, mirasçılardan birinin veya birkaçının belirli bir şey veya hisse üzerine uzlaşarak terikeden çekilmesidir. Mesela mirasçllardan dörtte bir hissesi olan bir kimse diğer varislerle belli bir mal ya da bește bir hisse üzerine sulh olsa buna tehârüc denir. bk. Mehmet Erdoğan, Fıkıh ve Hukuk Terimleri Sözlüğü (İstanbul: Ensar Yayınları, 2015), tehârüc md. 559.
} 
münâseha ${ }^{108}$ gibi bölümlerinde bu gibi rızâî taksimin örnekleri bol miktarda bulunmaktadır.

\section{Sonuç}

Araştırma sonucunda Türk mer'i miras hukuku ile İslam miras hukuku arasında ilke bazında bazı benzerlikler bulunmasına rağmen, önemli düzeyde birtakım farklılıkların da bulunduğu tespit edilmiştir. Her iki hukuk sisteminin de miras bırakana, hayatında olduğu gibi ölümünden sonra da malında tasarruf imkânı tanıyor olması, varise zarar vermek veya öldürmenin mirastan mahrumiyete sebep olması, benzerlik noktaları olarak karşımıza çıkmaktadır. Bunun yanında ilahi ve beşerî olarak kaynaklarının farklılı̆̆l, mirasçıların tespiti, kanuni ve mansup mirasçılık, zümre sistemi, intifa hakkı, füruu varken anne babanın mirasçılığı, miras bırakanın borcunun varisler tarafından ödenmesinde kendi mallarıla müteselsil sorumluluk, mahfuz hisseler, feragat, ıskat, iade, kazâî ve rızâî taksim vb. birçok konuda, ilke bazında önemli farklılıkların bulunduğu tespit edilmiştir. Söz konusu bu benzerlik ve farklılıklar birlikte değerlendirildiğinde, özellikle adalet kavramının farklı anlamları da dikkate alınarak, İslam miras hukukunun miras dağıtım ilkelerinin daha adil bir paylaşım öngördügü söylenebilir.

108 Münâseha, terikenin taksiminden önce, mirasçılarının birinin veya birkaçının daha ölmeleri ile, bunlara düșen hisselerin kendi mirasçılarına kalmış olmasıdır. bk. Berki, Íslam Hukukunda Feraiz ve İntikal, 157; Münâsaha, mirasta tedâhül demektir. Bir ölünün terikesi henüz taksim edilmeden varislerden biri veya birkaçı da vefat edip, o terikeden sehimlerinin kendi varislerine intikal etmesidir. bk. Erdoğan, Fıkıh ve Hukuk Terimleri Sözlüğü, münâsaha md. 421. 


\section{Kaynakça}

Akgündüz, Said Nuri. "Hikmet-i Teşrî‘ Açısından Miras Paylarıyla İlgili Bazı Hükümlerin Yorumlanması". Katre Uluslararası Insan Araştırmaları Dergisi 10 (31 Aralık 2020), 183-201.

Alkış, Alpaslan. "İslam Miras Hukuku İle Türk Medeni Kanun Miras Sisteminin Varisler Yönüyle Karşılaştırılması". Çukurova Üniversitesi Illahiyat Fakültesi Dergisi (ÇÜiFD) 19/1 (26 Haziran 2019), 60-79. https://doi.org/10.30627/cuilah.541225

Altuntaş, Halil - Şahin, Muzaffer. Kur'an-ı Kerim Meâli. Ankara: Diyanet İşleri Başkanlığı Yayınları, 22. Basım, 2012.

Atay, Ender Ethem vd. Temel Hukuk Bilgisi. ed. Hüseyin Özcan. Eskișehir: Anadolu Üniversitesi, 2020.

Ayiter, Nûşin - Kılıçoğlu, Ahmet M. Miras Hukuku. Yetkin, 1989.

Bardakoğlu, Ali. "Ferâiz". Türkiye Diyanet Vakfı İslâm Ansiklopedisi. 12/362-363. İstanbul: Türkiye Diyanet Vakfı Yayınları, 1995.

Berki, Ali Himmet. İslam Hukukunda Feraiz ve İntikal. İstanbul: Güzel İstanbul Matbaası.

Berki, Ali Himmet. Íslam Hukukunda Feraiz ve Intikal. Ankara: Emel Matbaacılık, 3. Basım.

Berki, Şakir. "Türk Miras Hukukunun Esasları". Ankara Üniversitesi Hukuk Fakültesi Dergisi 11/3 (01 Mayıs 1954), 0-0. https://doi.org/10.1501/Hukfak_0000001234

Berrâc Cum'a Muhammed Muhammed, Cum'a Muhammed Muhammed. Ahkâmü'l-Mevârîs fi'şŞerî́ati'l-İslâmiyye. Amman: Dâru'l-Fikr, 1. Basım, 1981.

Bilmen, Ömer Nasuhi. Hukuk-ı İslamiyye ve Istılahat-ı Fıkhiyye Kamusu. 8 Cilt. İstanbul: Bilmen Basımevi, 1969.

Buhârî, Ebû Abdillah Muhammed b. İsmail. Sahîh. 9 Cilt. Dâru Tavkı'n-Necât, 1. Basım, 1422.

Cerah, Zeynep. "Gözetilen Hikmetler Açısından Fıkıh'ta Kadınların Mirası”, 295.

Cübbûrî, Ebü'l-Yakzân Atıyye el-. Hükmü'l-Mîrâs fi'ş-Șerî’ati'l-İslâmiyye. Bağdat: Dâru'n-Nezîr, 1. Basım, 1969.

Cündî, Muhammed eş-Șehhât el-. el-Mîrâs fi'ş-Şerî’ati'l-İslâmiyye. Kahire: Dâru'l-Fikri'l-Arabî, ts.

Çolak, Abdullah. İslam Aile Hukuku. İstanbul: Ensar, 1. Basım, 2018.

Çuçak, Muhammed. "İslam Miras Hukukunda Asabe Ve Bu Yolla Mirasçı Olmak". Süleyman Demirel Üniversitesi Illahiyat Fakültesi Dergisi 45 (31 Aralık 2020), 25-43.

Dârimi, Ebû Muhammed Abdullah b. Abdurrahman. Sünen. Suudi Arabistan: Dâru'l-Muğnî, 1. Basım, 1412.

Derâdeke, Yasin Ahmed İbrahim. el-Mîrâs fi'ş-Şerî'ati'l-İslâmiyye. Beyrut: Müessesetü'r-Risâle, 2. Basım, 1983.

Doğan, D. Mehmet. Büyük Türkçe Sözlük. İstanbul: İz Yayıncılık, 11. Basım, 1996.

Dursunüst, Elif. "Kabul Edilme Sürecinde Türk Kanun-ı Medenîsi”. Usul İslam Araştırmaları 34/34 (31 Ekim 2020), 159-170.

Erdoğan, Mehmet. Fıkıh ve Hukuk Terimleri Sözlüğü. İstanbul: Ensar Yayınları, 5. Basım, 2015. Gökmenoğlu, Hüseyin Tekin. “İslam Miras Hukukunda 'Halefiyet', 'Dede Yetimi' ve 'Vacip Vasiyet”'. Dini Araștırmalar 1/3 (01 Haziran 1999).

Hatarâvî, Muhammed el-'Iyd el-. er-Râid fî 'Ílmi'l-Ferâiz. Medîne-i Münevvere: Mektebetü Dâri't-Türâs, 4. Basım, ts.

İmre, Zahit - Erman, Hasan. Miras Hukuku. Beta, 1989.

İnan, Ali Naim vd. İnan Türk Medeni Hukuku Miras Hukuku. Ankara: Seçkin, 7. Basım, 2008.

Kaneti, Selim. "Türk Miras Hukukunun Anayasal Temelleri". Journal of Istanbul University Law Faculty 54/1-4 (12 Temmuz 2011), 237-244. 
Karaman, Hayreddin. Mukayesei İslâm Hukuku. İstanbul: Nesil Yayınları, 5. Basım, 1996.

Karaman, Hayreddin. Yeni Gelişmeler Karşısında İslâm Hukuku. İstanbul: İz Yayınclık, 6. Basım, 2011.

Keskioğlu, Osman. Fıkıh Tarihi ve İslam Hukuku. Ankara: Diyanet İşleri Başkanlı̆̆ı, 5. Basım, 1999.

Kılıçoğlu, Ahmet. Medeni Kanunumuzu Nasıl Değiştirdik. 3 Cilt. Marmara Üniversitesi Hukuk Fakültesi Hukuk Araştırmaları Dergisi, 2016.

Kişkî, Muhammed Abdürrahim el-. el-Mîrâsü'l-Mukâran. Bağdat: Dâru'n-Nezîr, 3. Basım, 1969.

Kuduri, Ebu'l-Huseyn Ahmed b. Ebubekir Muhammed b. Ahmed. Muhtasaru'l-Kudûrî. ed. Faik Akcaoğlu. İstanbul: Beka Yayıncllık, 2018.

Mahlûf, Haseneyn Muhammed. el-Mevârîs fi'ş-Şerî'ati'l-İslâmiyye. Mısır: Dâru'l-Kitâbi'l-'Arabî, 2. Basım, 1954.

Müslim, Mustafa. Mebâhis fí 'Ílmi'l-Mevârîs. Cidde: Dâru'l-Menâra, 5. Basım, 2004.

Müslim, Müslim b. Haccâc Ebü'l-Hasen el-Kușeyrî en-Nîsâbûrî. Sahîh. 5 Cilt. Beyrut: Dâru İhyâi't-Türâsi'l-Arabî, ts.

Okur, Kaşif Hamdi. "İslam Hukukunda Miras Engeli Olarak Müslüman Ve Gayrimüslim Arasındaki Din Ayrılığı". Dinbilimleri Akademik Araştırma Dergisi 7/2 (01 Nisan 2007), 95-120.

Özay, Hilal. "İslam Miras Hukukunun Özellikleri". İslam Medeniyeti Araştırmaları Dergisi 3/2 (31 Aralık 2018), 203-224. https://doi.org/10.20486/imad.475629

Özdirek, Recep - Çavuşoğlu, Ali Hakan. "Süfyân es-Sevrî". Türkiye Diyanet Vakfi İslâm Ansiklopedisi. 38/23-28. İstanbul: Türkiye Diyanet Vakfı Yayınları, 2010.

Özel, Ahmet. Hanefi Fıkıh Alimleri ve Diğer Mezheplerin Meșhurları. Ankara: TDV, 4. Basım, 2014.

Öztrak, İlhan. Miras Hukuku (Giriş-Kanundan Doğan Mirasçllı-Ölüme Bağlı Tasarruflar). Ankara.

Sâbûnî, Muhammed Ali es-. el-Mevârîs fi'ş-Şerî'ati'l-İslâmiyye fí Dav'i'l-Kitâbi ve's-Sünne. Mekkei Mükerreme: Dâru'l-Hadîs, ts.

Serahsî, Şemsüleimme es-. el-Mebsût. XXX Cilt. Beyrut: Dâru'l-Ma'rife, 1993.

Şerbasi, Ahmet. İslam Flkhı. çev. Mustafa Özcan vd. 8 Cilt. İstanbul: Özgü Yayınları, 2. Basım, 2011.

Taş, Erhan. "Kabul Sürecinde Türk Medeni Kanunu'na Yönelik Bazı Eleștiriler”. Bingöl Üniversitesi Sosyal Bilimler Enstitüsü Dergisi 8/16 (2018), 649-670. https://doi.org/10.29029/busbed.422925

Tirmizi, Muhammed b. İsa b. Sevra b. Musa b. Dahhâk. Sünen. 6 Cilt. Beyrut: Dâru'l-Ğarbi'lİslami, 1998.

Topuz, Murat vd. Medeni Hukuk Bilgisi. ed. Hayriye Şen Doğramacl. Eskişehir: Anadolu Üniversitesi, 2020.

Useymîn, Muhammed b. Sâlih el-. Telhîsu Fıkhi'l-Ferâiz. Riyad: Medâru'l-Vatan, 1423.

Yazıcl, Abdurrahman. "Fıkıhta Meşhur Bir Miras Meselesi Olarak Ömeriyyeteyn: Kaynağı, Ortaya Çııtığı Haller ve Çözümü". Ondokuz Mayıs Üniversitesi İlahiyat Fakültesi Dergisi 35/35 (01 Eylül 2013), 223-244. https://doi.org/10.17120/omuifd.71818

Yazıcı, Abdurrahman. İslam Hukukunda Asabe Yoluyla Mirasçıllk. İstanbul, Dr, 2011.

Yazıcı, Abdurrahman. "İslam Miras Hukuku İle Türk Medeni Kanunu Miras Sisteminin Mukayesesi". Ekev Akademi Dergisi, 14.

Yazıcı, Abdurrahman. "Üç Ferâiz Metni Çerçevesinde Gelişen Müteahhirîn Dönemi Ferâiz Literatürü”. Türkiye Araştırmaları Literatür Dergisi 11/22 (2013), 147-192. 
Mecelle, Mecelle-i Ahkam-1 Adliye (ts.).

Osmanlı Hukuk-ı Aile Kararnamesi. Konya: Mehir Vakfı Yayınları, 5. Basım, 2017.

TBK, Türk Borçlar Kanunu. Resmi Gazete 6098 (11 Ocak 2011).

TMK, Türk Medeni Kanunu. Resmi Gazete 4721 (22 Kasım 2001).

TMK (Eski), Türk Medeni Kanunu (Eski). Resmi Gazete 743 (17 Şubat 1926).

Türkiye Cumhuriyeti Anayasası, Türkiye Cumhuriyeti Anayasası. 2709 (18 Ekim 1982). 